\title{
Wind tunnel experiments on the retention of trace gases during riming: nitric acid, hydrochloric acid, and hydrogen peroxide
}

\author{
N. von Blohn ${ }^{1}$, K. Diehl ${ }^{1}$, S. K. Mitra ${ }^{1}$, and S. Borrmann ${ }^{1,2}$ \\ ${ }^{1}$ Institute of Atmospheric Physics, Johannes Gutenberg University, Mainz, Germany \\ ${ }^{2}$ Max Planck Institute of Chemistry, Mainz, Germany \\ Received: 16 May 2011 - Published in Atmos. Chem. Phys. Discuss.: 22 June 2011 \\ Revised: 3 November 2011 - Accepted: 6 November 2011 - Published: 21 November 2011
}

\begin{abstract}
Laboratory experiments were carried out in a vertical wind tunnel to study the retention of different atmospheric trace gases during riming. In the experiments, the rimed ice particles floated in a laminar air stream carrying a cloud of supercooled droplets with radii between 10 and $20 \mu \mathrm{m}$. Ice particles, dendritic ice crystals, and snow flakes with diameters between $6 \mathrm{~mm}$ and $1.5 \mathrm{~cm}$ were allowed to rime at temperatures between -5 and $-12{ }^{\circ} \mathrm{C}$ where riming mainly proceeds in the atmosphere and with cloud liquid water contents between 1 and $1.5 \mathrm{~g} \mathrm{~m}^{-3}$ which are values typically found in atmospheric mixed-phase clouds. Three trace species were investigated, nitric and hydrochloric acid, and hydrogen peroxide. They were present in the supercooled liquid droplets in concentrations from 1 to $120 \mathrm{ppmv}$, i.e. similar to the concentrations measured in cloud drops. The chemical analyses of the rimed ice particles allow one to determine the trace species concentration in the ice phase. Together with the known liquid phase concentration the retention coefficients were calculated in terms of the amount of the species which remained in the ice phase after freezing. It was found that the highly soluble trace gases, nitric and hydrochloric acid, were retained nearly completely $(98.6 \pm 8 \%$ and $99.7 \pm 9 \%$, respectively) while for hydrogen peroxide a retention of $64.3 \pm 11 \%$ was determined. No influence of the riming temperature on the retention was found which can be explained by the fact that in the observed range of temperature and liquid water content, riming proceeded in the dry growth regime.
\end{abstract}

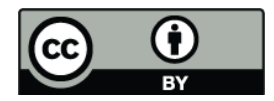

Correspondence to: N. von Blohn (vonblohn@uni-mainz.de)

\section{Introduction}

Precipitation in tropospheric mixed-phase clouds where ice particles and supercooled liquid drops are simultaneously present is mostly initiated via the ice phase. Processes leading to the growth of ice particles to precipitation sizes are the diffusion of water vapor (Bergeron Findeisen process) and riming, i.e. the deposition of liquid droplets on ice particles such as frozen drops and ice crystals (Pruppacher and Klett, 1997). An important aspect of the riming process lies in the field of cloud chemistry: The retention of water-soluble trace gases during riming represents a way of scavenging via the ice phase. Only a fraction of the trace species is transferred from the impinging liquid droplets into the ice, the rest being released back into the gas phase. Thus, the retention of trace gases is affecting their partitioning between the phases, scavenging and life time, and their pathway in the atmosphere. As an example, $\mathrm{H}_{2} \mathrm{O}_{2}$ is produced mainly in the lower and midtroposphere but model studies indicate that it could reach the upper troposphere if it is released during freezing processes at high altitudes (e.g., Mari et al., 2000). Thus, the $\mathrm{HO}_{\mathrm{x}}$ budget is significantly impacted by either a complete wash-out of $\mathrm{H}_{2} \mathrm{O}_{2}$ in deep convective clouds because of its high solubility or by partial release back to the gas phase during ice formation (e.g., Prather and Jacob, 1997). In model simulations, Salzmann et al. (2007) found that the retention coefficients of highly soluble trace gases are essential for their scavenging and re-distribution in the upper troposphere.

In field measurements, higher amounts of trace species were found in rimed snow samples than in unrimed samples which confirm the importance of riming for precipitation chemistry in mixed-phase clouds (e.g., Borys et al., 1988, Collett et al., 1991; Harimaya and Nakai, 1999). Laboratory studies support this conclusion because trace gases like $\mathrm{SO}_{2}$,

Published by Copernicus Publications on behalf of the European Geosciences Union. 
$\mathrm{HNO}_{3}, \mathrm{HCl}$, and $\mathrm{NH}_{3}$ are taken up by ice crystals in significantly lower amounts than by water drops (e.g., Mitra et al., 1990; Diehl et al., 1995, 1998; Hoog et al., 2007). Thus, riming might be the major process to incorporate these trace gases into the ice phase.

The retention coefficients are affected by the characteristics of the trace gases (Stuart and Jacobson, 2003). Highly soluble gases such as $\mathrm{HNO}_{3}$ and $\mathrm{HCl}$ are almost completely dissociated in water so that ions are hardly able to leave the liquid phase. This should lead to a high retention of these gases. In comparison, gases such as $\mathrm{NH}_{3}$ or $\mathrm{SO}_{2}$ are not that highly dissociated in water, while $\mathrm{H}_{2} \mathrm{O}_{2}$, for instance, is almost not dissociated but only dissolved in water. For these trace gases one would expect lower retention during riming. All the mentioned species were investigated earlier in several laboratory studies; however, these led to controversial results. Iribarne et al. (1983) measured a retention of $25 \%$ for $\mathrm{SO}_{2}$ while Lamb and Blumenstein (1987) found 1 to $12 \%$ only. Later Iribarne et al. (1990) determined an even higher retention for $\mathrm{SO}_{2}$ of $60 \%$. For $\mathrm{H}_{2} \mathrm{O}_{2}$, Iribarne and Physnov (1990) determined 100\% retention but Snider et al. (1992) measured $25 \%$ only and Snider and Huang (1998) observed $5 \%$. The uncertainties of measurements indicated by the authors were below $10 \%$ (absolute values). Thus, these strongly deviating values were probably caused by differences in experimental conditions which were in some cases quite far from those occurring in the real atmosphere. Some of these studies were performed in a cloud chamber with impaction cylinders or rotating rods as riming objects; in others flat collecting surfaces were used. In some cases the rime surface was ventilated.

Thus, the goal of the present investigation was to study the riming process under simulated more realistic atmospheric conditions: Ice crystals and particles have been freely or at least captively floated in the Mainz vertical wind tunnel at their terminal velocities ensuring that the ventilation coefficient during the experiments has the correct magnitude. From these experiments and the subsequent chemical analyses of the melt water, more precise retention coefficients were expected. The measurements were performed in the wind tunnel with ice particles and snow flakes which grew by collecting supercooled droplets. The supercooled droplets with radii between 10 and $20 \mu \mathrm{m}$ contained dissolved trace species. In the present study, nitric acid $\left(\mathrm{HNO}_{3}\right)$, hydrochloric acid $(\mathrm{HCl})$, and hydrogen peroxide $\left(\mathrm{H}_{2} \mathrm{O}_{2}\right)$ were used. Retention near $100 \%$ was expected for the highly soluble gases nitric acid and hydrochloric acid which were investigated first. This way earlier results could be confirmed for validation of the adopted experimental methods and for detailed error analysis. Afterwards, hydrogen peroxide was investigated for which earlier investigations gave widely differing retention coefficients. In a forthcoming study, the trace gases sulfur dioxide and ammonia will be considered.

\section{Experimental methods}

\subsection{Vertical wind tunnel}

The experiments were performed in the Mainz vertical wind tunnel which allows free levitation of hydrometeors (droplets, ice particles, ice crystals, snow flakes, hailstones) from micrometer to centimeter sizes at their respective terminal velocities in a vertical air stream. Single events can be observed under controlled temperatures between $30^{\circ} \mathrm{C}$ and $-30^{\circ} \mathrm{C}$, dew points from $-40^{\circ} \mathrm{C}$ to saturation (ambient temperature) and wind speeds from $10 \mathrm{~cm} \mathrm{~s}^{-1}$ up to $40 \mathrm{~m} \mathrm{~s}^{-1}$. For its entire range of air speeds the tunnel shows a turbulence level of less than $0.5 \%$ (Vohl, 1989). More details of the wind tunnel design and construction can be found in Pruppacher (1988) and in the review articles of Szakáll et al. (2010) and Diehl et al. (2011).

The present experiments were carried out in a way similar to those carried out recently where the collection kernels of ice particles and riming droplets have been investigated (von Blohn et al., 2009). During the experiments presented here single ice particles, crystals, or snow flakes grew by collision within a cloud of supercooled droplets which was produced upstream of the observation section by an array of sprayers. The sprayers were installed on the walls of the mixing chamber of the wind tunnel to prevent freezing of the sprayer nozzles. Thus, the temperature of the droplets was above $0{ }^{\circ} \mathrm{C}$ when they entered the wind tunnel; however, by the time they reached the experimental section their temperature was in equilibrium with the air temperature of the wind tunnel. The size spectrum of the cloud of liquid droplets was determined inside the experimental section with a Classical Scattering Aerosol Spectrometer Probe (CSASP, Particle Measuring Systems) and shows droplet radii between 4 and $22 \mu \mathrm{m}$ with a median volume radius of approximately $15 \mu \mathrm{m}$ (for more details see von Blohn et al., 2009). The conditions during the experiments were similar to those typical for riming in atmospheric mixed-phase clouds, i.e. temperatures from -5 to $-12{ }^{\circ} \mathrm{C}$ and liquid water contents lying between 1 and $1.5 \mathrm{~g} \mathrm{~m}^{-3}$ (Pruppacher und Klett, 1997). It was shown that in these observed ranges of temperature and liquid water content the growth of the ice particles proceeds in the dry growth regime (von Blohn et al., 2009). That means that despite the increase of the surface temperature of the rimed ice particles by the release of latent heat, the surface temperature definitely stays below $0^{\circ} \mathrm{C}$. Therefore, liquid drops colliding with the ice particle freeze immediately after contact.

\subsection{Liquid phase concentrations}

During the experiments described here, the liquid droplets contained defined concentrations of the trace gas to be studied $\left(\mathrm{HNO}_{3}, \mathrm{HCl}\right.$, or $\left.\mathrm{H}_{2} \mathrm{O}_{2}\right)$. Non-volatile salts were added to the solution as tracers $\left(\mathrm{Na}_{2} \mathrm{SO}_{4}, \mathrm{KH}_{2} \mathrm{PO}_{4}\right.$, or $\left.\mathrm{KNO}_{3}\right)$. These tracers remained entirely within the droplets during freezing 
Table 1. Composition of the riming droplets with solved gases and salt tracers (errors $\pm 3 \%$ maximum).

\begin{tabular}{llll}
\hline nitric acid & solution 1 & solution 2 & solution 3 \\
\hline $\mathrm{HNO}_{3}$ & $120 \mathrm{ppmv}$ & $12 \mathrm{ppmv}$ & $120 \mathrm{ppmv}$ \\
$\mathrm{Na}_{2} \mathrm{SO}_{4}$ (tracer) & $70 \mathrm{ppmv}$ & $10 \mathrm{ppmv}$ & - \\
$\mathrm{H}_{2} \mathrm{SO}_{4}$ (tracer) & - & - & $10 \mathrm{ppmv}$ \\
\hline hydrochloric acid & solution 1 & solution 2 & solution 3 \\
\hline $\mathrm{HCl}$ & $90 \mathrm{ppmv}$ & $50 \mathrm{ppmv}$ & $17 \mathrm{ppmv}$ \\
$\mathrm{Na}_{2} \mathrm{SO}_{4}$ (tracer) & $120 \mathrm{ppmv}$ & $70 \mathrm{ppmv}$ & $20 \mathrm{ppmv}$ \\
\hline hydrogen peroxide & solution 1 & solution 2 & \\
\hline $\mathrm{H}_{2} \mathrm{O}_{2}$ & $10 \mathrm{ppmv}$ & $1 \mathrm{ppmv}$ & \\
$\mathrm{KH}_{2} \mathrm{PO}_{4}$ (tracer) & $40 \mathrm{ppmv}$ & - & \\
$\mathrm{KNO}_{3}$ (tracer) & - & $0.4 \mathrm{ppmv}$ & \\
$\mathrm{Na}_{2} \mathrm{SO}_{4}$ (tracer) & - & $0.8 \mathrm{ppmv}$ & \\
\hline
\end{tabular}

so that the amount of liquid water deposited on the ice particles could be determined afterwards, using the method of Iribarne and Physnov (1990). In that way errors caused by evaporation of the droplets could be compensated (details in next section). Table 1 shows the concentrations of gases and tracers in the droplet solutions during our experiments. As much as possible, the concentration of the trace gases in the liquid phase was chosen similarly to concentrations found in atmospheric cloud droplets. Field measurements of $\mathrm{HNO}_{3}$ (measured as $\mathrm{NO}_{3}^{-}$in cloud water) range from 0.5 to $100 \mathrm{ppmv}$ with average values between 12 and $19 \mathrm{ppmv}$; cloud water concentrations of $\mathrm{HCl}$ (measured as $\mathrm{Cl}^{-}$) are between 0.1 and $110 \mathrm{ppmv}$ with mean values of 6 to $40 \mathrm{ppmv}$ (e.g., Römer et al., 1985; Warneck, 2000; Pruppacher and Klett, 1997; Neal et al., 2007). Thus, for nitric and hydrochloric acid, the experimental liquid phase concentrations of 12 and $120 \mathrm{ppmv}$, and 17, 50, and $90 \mathrm{ppmv}$, respectively (see Table 1), were on the order of the average and maximum concentrations measured in cloud water. Regarding $\mathrm{H}_{2} \mathrm{O}_{2}$, cloud water concentrations are much lower with average values around $0.1 \mathrm{ppmv}$ and maximum $0.5 \mathrm{ppmv}$ (e.g., Sauer et al., 1996; Valverde-Canossa et al., 2005). In this case, the liquid phase concentrations used in the experiments, i.e. 1 and 10 ppmv (see Table 1) were up to one order of magnitude higher because lower liquid phase concentrations produced too low concentrations in rime ice leading to large uncertainties during analysis.

\subsection{Experimental description}

Performing the experiments with completely freely floating small ice particles as described in von Blohn et al. (2009) did not lead to good statistics for accurate results. The time periods to freely suspend frozen drops were too short to accumulate sufficient material that allows an acceptable level of accuracy in the analyses. However, preliminary tests with $\mathrm{HNO}_{3}$ and $\mathrm{HCl}$ indicated that this caused unavoidable large uncertainties in the measurements. Therefore, the experiments were performed mostly with captively or quasifloating ice particles and crystals.

In a first set, experiments with any of the three trace species $\left(\mathrm{HNO}_{3}, \mathrm{HCl}\right.$, or $\left.\mathrm{H}_{2} \mathrm{O}_{2}\right)$ were carried out with captively floating ice particles of about $8 \mathrm{~mm}$ in diameter which were tethered using a very thin nylon fiber. Thus, they were freely movable in the air stream while supported at their free fall velocities so that heat transfer between ice particle and environment could take place in a way similar to that occurring in the real atmosphere. Along the nylon fiber negligible heat conduction occurs so that the temperature of the ice particle was not affected by the connecting fiber. The ice particles were prepared inside the walk-in cold chamber of the Mainz wind tunnel laboratory in small moulds in a way that deionised and distilled water froze around the nylon fiber. Afterwards, the ice particle was transferred to the wind tunnel inside an isolated box which was mounted at a connection port on the wind tunnel wall. From there it could be moved towards the centre of the tunnel while hanging from a thin rod. The ice particles were weighted before and after riming to determine the initial ice mass and the collected rimed mass to calculate the dilution of the collected sample. The captively floating ice particle was continuously exposed to a supercooled droplet cloud of the investigated solution and was allowed to rime for 15 to $20 \mathrm{~min}$. Subsequently, the rimed graupel was taken out of the wind tunnel section and put into a small sample container and analyzed upon melting. Simultaneously, a Teflon rod was rimed in the experimental section to get a pure rime ice sample without an ice core. From this reference sample the evaporation of the riming droplets on their way from the sprayers to the experimental section was determined via the tracer concentration.

In a second set of experiments, dendritic ice crystals were used. They were produced from deionised water in a deposition growth chamber installed inside the walk-in cold chamber (see, e.g., Diehl et al., 1998; Hoog et al., 2007). In case of the $\mathrm{H}_{2} \mathrm{O}_{2}$ experiments, composites of ice crystals were assembled to yield large snow flakes of about 1 to $1.5 \mathrm{~cm}$ diameter. Each snow flake was transported to the wind tunnel on a coarse meshed net of extremely fine nylon fibers inside an isolated box. This box was mounted at the wind tunnel connection port, the net was moved into the centre of the tunnel, and the air speed in the tunnel was set in such a way that the snow flake was quasi-floating on the net. Thus, the wind speed was equal to the terminal velocity of the snow flake. When exposed to the riming droplets, the snow flakes sampled a large number of supercooled droplets because of their large surface area which reduced measurement uncertainties during analysis. After a riming time of 15 to $20 \mathrm{~min}$ the net with the rimed snow flake was moved back into the insulation box and re-transferred to the walk-in could chamber avoiding contact with tunnel walls to minimize contamination. There, it was put into a sample container where the rimed snow flake melted. 
In case of $\mathrm{HNO}_{3}$ and $\mathrm{HCl}$ the second set of experiments was performed with freely floating dendritic ice crystals of approximately $6 \mathrm{~mm}$ length. Each of them was transported to the wind tunnel on a fine net inside the insulation box. After the box was mounted at the tunnel, the net was moved into the centre of the wind tunnel and turned upside down so that the ice crystal fell off ending up freely floating in the air stream. After a riming time between one and two minutes, the ice crystal was extracted from the wind tunnel section with a cuvette that was brought into the experimental section through an air lock. In order to collect sufficient ice mass for a reasonable chemical analysis, 3 to 5 rimed ice crystals had to be put together in one sample box. As a minimum amount of liquid is required for the analysis 500 $\mu 1$ pure distilled water was added to the samples. Because of this dilution, these experiments could be performed only with the maximum concentrations of $\mathrm{HNO}_{3}$ or $\mathrm{HCl}$ in the solution droplets ( 50 and 120 ppmv). In the case of $\mathrm{H}_{2} \mathrm{O}_{2}$, even with higher concentrations in the liquid phase, the amount of retained material in the ice phase was below the detection limit.

As in the first set of experiments, pure rime ice samples were taken in the experimental section on a Teflon rod. From these reference samples both the dilution of the collected rimed snow flakes and the evaporation of the riming droplets was determined via the tracer concentration.

To summarize, the riming experiments with $\mathrm{HNO}_{3}$ and $\mathrm{HCl}$ were performed using captively floating ice particles and freely floating ice crystals. Experiments with $\mathrm{H}_{2} \mathrm{O}_{2}$ were performed with captively floating ice particles and quasi-floating snow flakes.

\subsection{Chemical analyses and evaluation}

The retention coefficients of $\mathrm{HNO}_{3}, \mathrm{HCl}$, and $\mathrm{H}_{2} \mathrm{O}_{2}$ were determined from the amount of the species in the melt water of the grown ice particles, crystals, or snow flakes, and the amount of the species in the supercooled liquid droplets. The amounts of the tracer materials $\left(\mathrm{Na}_{2} \mathrm{SO}_{4}, \mathrm{KH}_{2} \mathrm{PO}_{4}\right.$, or $\mathrm{KNO}_{3}$ ) in ice were used to correct errors caused by evaporation of droplets on their way from the sprayers to the experimental section. Nitrate, chloride, sulfate, and phosphate were determined by ion chromatography (DIONEX 2000i and DIONEX ICS-1000) using appropriate separation columns, suppressors, and eluents. Hydrogen peroxide was analyzed by high performance liquid chromatography (HPLC) equipped with a spectrofluorometric detector.

Regarding the liquid phase concentrations in the supercooled droplets, these were stable during the experiments in case of $\mathrm{HNO}_{3}$ and $\mathrm{HCl}$ because they are completely dissolved and dissociated in the liquid and, therefore, do not easily desorb (Pruppacher and Klett, 1997). However, the situation was different with $\mathrm{H}_{2} \mathrm{O}_{2}$ dissolved in the supercooled droplets as it is not stable in the liquid phase but tends to desorb from the solution droplets and to decompose inside the droplets into water and oxygen. Therefore, the liquid phase concentrations had to be corrected. When the droplets were released from the sprayers into the tunnel they cooled down from positive temperatures near $0{ }^{\circ} \mathrm{C}$ to the experimental temperature between -5 and $-12^{\circ} \mathrm{C}$. This temperature adaption time was calculated according to Pruppacher and Klett (1997) and found to be on the order of a second. As generally all reaction rates are decelerated at low ambient temperatures it was assumed that after reaching the ambient air temperature the loss processes slowed down so that they could be neglected until the droplets rimed on ice. Thus, the maximal desorption and decomposition was to be expected during this first second just after the solution was sprayed out from the bottle container. The amount of reduction was determined from a detailed sprayer statistics before starting the riming experiments. The solution concentrations before entering the sprayers and directly after leaving the sprayers were compared so that the actual liquid phase concentration present during riming could be determined. These measurements indicated that on the average between $16 \%$ (with higher liquid phase concentrations) and $37 \%$ (with lower liquid phase concentrations) of $\mathrm{H}_{2} \mathrm{O}_{2}$ concentration were lost during sprayer atomization.

In cases of $\mathrm{HNO}_{3}$ and $\mathrm{HCl}$, the retention coefficient $R$ was calculated from the concentration of the collected sample after riming $C_{\text {sample }}$, the liquid phase concentration $C_{\text {liq }}$, the collected mass of the rimed sample $m_{\text {sample }}$, the rime mass $m_{\text {rime }}$, the liquid phase concentration of the tracer $C_{\text {trac,liq, }}$, and the concentration of the tracer in the reference sample $C_{\text {trac, ref }}$ according to the following equation

$R=\frac{C_{\text {sample }}}{C_{\text {liq }}} \frac{m_{\text {sample }}}{m_{\text {rime }}} \frac{C_{\text {trac,liq }}}{C_{\text {trac, ref }}}$

The second term on the right-hand side of Eq. (1) represents the dilution factor accounting for the dilution of the sample by the pure ice core, and the third term represents the evaporation factor due to changes of the liquid phase concentration by evaporation of the supercooled droplets.

In case of $\mathrm{H}_{2} \mathrm{O}_{2}$, the retention coefficient $R$ was calculated from the concentration of the collected sample after riming $C_{\text {sample }}$, the liquid phase concentration $C_{\text {liq,spray }}$, the concentration of the tracer in the reference sample $C_{\text {trac, ref }}$, the concentration of the tracer in the collected sample $C_{\text {trac,sample, }}$ and the liquid phase concentration of the tracer $C_{\text {trac, liq ac- }}$ cording to

$R=\frac{C_{\text {sample }}}{C_{\text {liq, spray }}} \frac{C_{\text {trac,ref }}}{C_{\text {trac, sample }}} \frac{C_{\text {trac, liq }}}{C_{\text {trac,ref }}}$

In the first term on the right-hand side of Eq. (2), $C_{\text {liq }}$ was replaced with $C_{\text {liq, spray }}$ which is the liquid phase concentration measured directly after the sprayers. This way the liquid phase concentration was corrected because inside the sprayer nozzle the $\mathrm{H}_{2} \mathrm{O}_{2}$ concentration was reduced by decomposition. The second term on the right-hand side of Eq. (2) represents the dilution factor accounting for the dilution of the 
Table 2. Retention coefficients of nitric and hydrochloric acid and hydrogen peroxide.

\begin{tabular}{|c|c|c|}
\hline & $\begin{array}{l}\text { retention } \\
\text { coefficient } \\
\text { (average value } \\
\text { with measuring } \\
\text { error) }\end{array}$ & $\begin{array}{l}\text { standard } \\
\text { deviation } \\
\text { (of all } \\
\text { data) }\end{array}$ \\
\hline \multicolumn{3}{|l|}{$\begin{array}{l}\text { nitric acid }\left(\mathrm{HNO}_{3}\right) \\
\text { ice particles captively floated }\end{array}$} \\
\hline $12 \mathrm{ppmv}$ & $0.95 \pm 0.07$ & 0.04 \\
\hline $\begin{array}{l}120 \text { ppmv } \\
\text { ice crystals freely floated }\end{array}$ & $1.02 \pm 0.08$ & 0.04 \\
\hline $120 \mathrm{ppmv}$ & $0.99 \pm 0.08$ & 0.03 \\
\hline \multicolumn{3}{|l|}{$\begin{array}{l}\text { hydrochloric acid }(\mathrm{HCl}) \\
\text { ice particles captively floated }\end{array}$} \\
\hline $17 \mathrm{ppmv}$ & $1.01 \pm 0.09$ & 0.05 \\
\hline $\begin{array}{l}90 \text { ppmv } \\
\text { ice crystals freely floated }\end{array}$ & $0.97 \pm 0.08$ & 0.04 \\
\hline 90 ppmv & $0.99 \pm 0.08$ & 0.04 \\
\hline \multicolumn{3}{|l|}{$\begin{array}{l}\text { hydrogen peroxide }\left(\mathrm{H}_{2} \mathrm{O}_{2}\right) \\
\text { ice particles captively floated }\end{array}$} \\
\hline $1 \mathrm{ppmv}$ & $0.74 \pm 0.11$ & 0.11 \\
\hline $\begin{array}{l}10 \text { ppmv } \\
\text { snow flakes quasi-floated }\end{array}$ & $0.60 \pm 0.10$ & 0.16 \\
\hline $1 \mathrm{ppmv}$ & $0.59 \pm 0.10$ & 0.15 \\
\hline
\end{tabular}

sample by the pure ice core, and the third term represents the evaporation factor due to changes of the liquid phase concentration by evaporation of the supercooled droplets.

\section{Experimental results}

\subsection{Nitric and hydrochloric acid}

The retention coefficients of the $\mathrm{HNO}_{3}$ experiments for captively floating ice particles are shown in Fig. 1 as a function of the ambient air temperature for two concentrations of $\mathrm{HNO}_{3}$ in the riming droplets of 12 ppmv (black circles) and $120 \mathrm{ppmv}$ (open circles). All values are around a retention coefficient of 1 within their errors and do not show any temperature dependence. In Fig. 2 the retention coefficients measured with freely floated ice crystals and a liquid phase concentration of $120 \mathrm{ppmv}$ are given for an average temperature of $-10 \pm 2{ }^{\circ} \mathrm{C}$. All data are again spread around a retention coefficient of 1 . In case of the $\mathrm{HCl}$ experiments, the results for the captively floated ice particles are plotted as function of the air temperature in Fig. 3. Two concentrations of the liquid phase concentration are explored, namely $17 \mathrm{ppmv}$ (black circles) and $90 \mathrm{ppmv}$ (open circles). Similar to the case of $\mathrm{HNO}_{3}$ (see Fig. 1), all values are around the retention coefficient of 1 and no temperature dependence has been observed. Figure 4 shows the retention coefficients of freely floated rimed ice crystals and a liquid phase concentration of $90 \mathrm{ppmv}$ for an average temperature of $-10 \pm 2{ }^{\circ} \mathrm{C}$ which

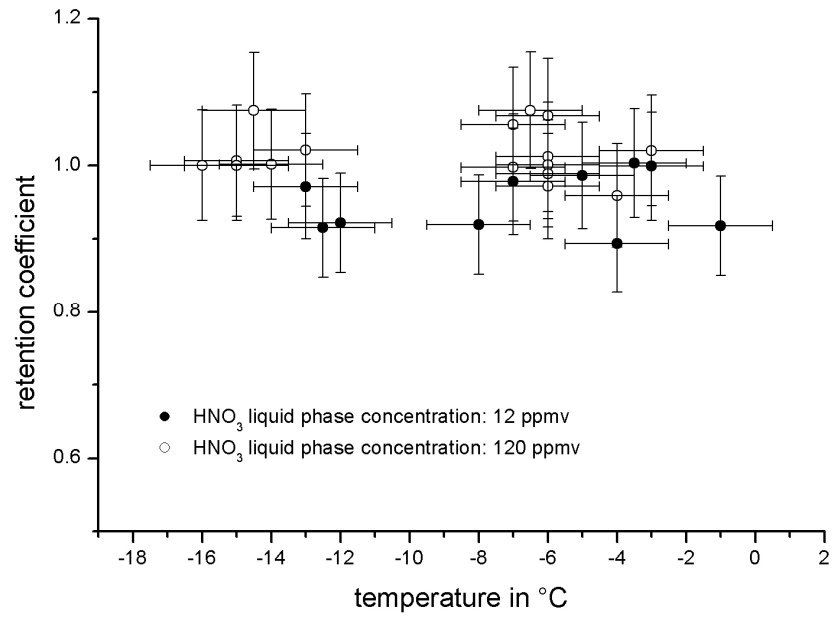

Fig. 1. Retention coefficient of $\mathrm{HNO}_{3}$ as a function of ambient air temperature, determined with captively floating ice particles rimed with solution droplets of two concentrations (black circles: 12 ppmv, open circles: 120 ppmv).

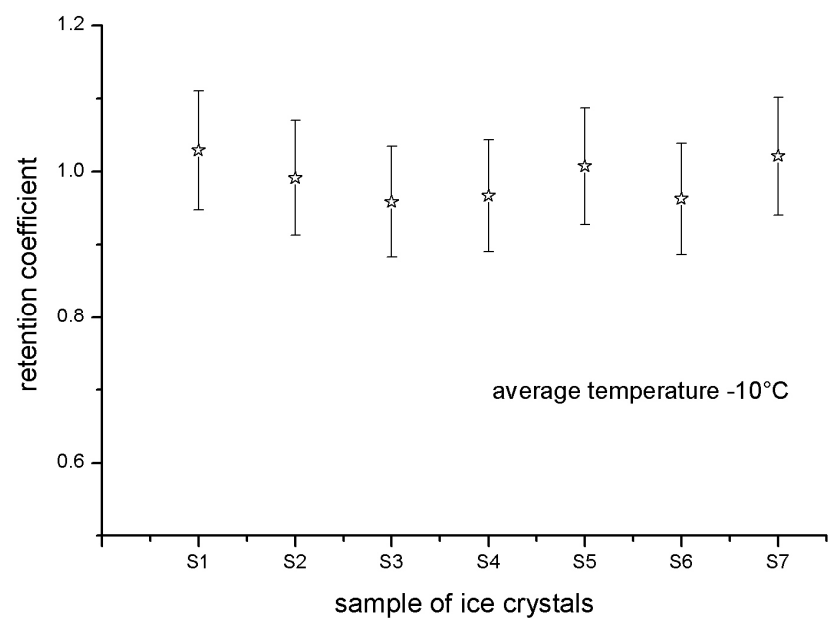

Fig. 2. Retention coefficient of $\mathrm{HNO}_{3}$, determined with freely floated ice crystals rimed with solution droplets with a concentration of 120 ppmv. Several samples at an average air temperature of $-10 \pm 2{ }^{\circ} \mathrm{C}$.

were spread around 1 , as it has been observed for $\mathrm{HNO}_{3}$ (see Fig. 2).

Each data point in Figs. 1 to 4 and all following figures represents one measurement. The errors of the temperature measurements were $\pm 1.5^{\circ} \mathrm{C}$; this value represents the standard deviation of the temperature during the riming time. The device error of the used temperature sensors was $\pm 0.25^{\circ} \mathrm{C}$. In Table 2 the mean values of the retention coefficients determined by different techniques and with various liquid phase concentrations are listed with errors which were calculated using the Gaussian error computation. The following factors are taken into account for these calculations: device errors 


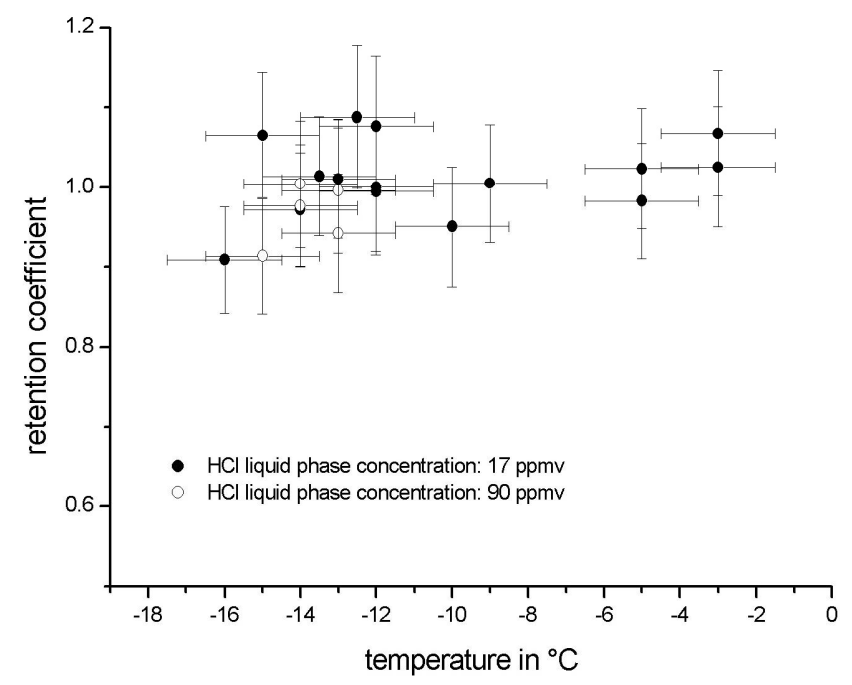

Fig. 3. Retention coefficient of $\mathrm{HCl}$ as a function of ambient air temperature, determined with captively floating ice particles rimed with solution droplets of two concentrations (black circles: 17 ppmv, open circles: 90 ppmv).

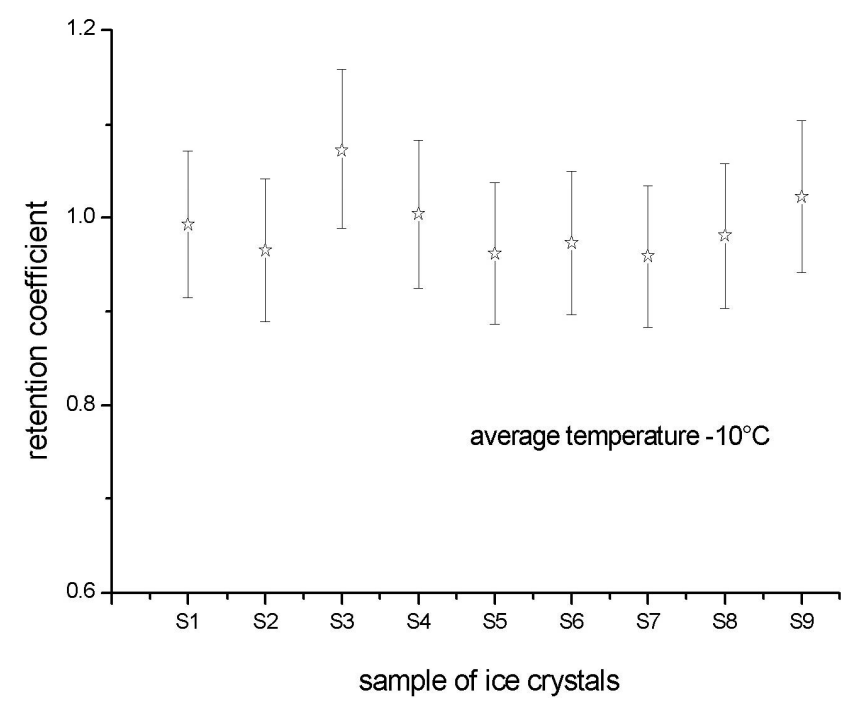

Fig. 4. Retention coefficient of $\mathrm{HCl}$, determined with freely floated ice crystals rimed with solution droplets with a concentration of $90 \mathrm{ppmv}$. Several samples at an average air temperature of $-10 \pm 2{ }^{\circ} \mathrm{C}$.

of the balances and the ion chromatographs, and calibration errors. The error bars in the figures represent the results of these computations. The column on the right hand side gives the standard deviations of all sampled data from the mean values. For nitrate and hydrochloride acid, it can be seen from Table 2 that the estimated errors caused by the measurement techniques are higher than the standard deviations from the scatter of the data. In case of $\mathrm{HNO}_{3}$ a retention coefficient of $0.95 \pm 0.07$ was determined for the captively floated ice particles with $12 \mathrm{ppmv}$ liquid phase concentration and a value of $1.02 \pm 0.08$ with $120 \mathrm{ppmv}$ liquid phase concentration. For the freely floated ice crystals with a $\mathrm{HNO}_{3}$ liquid phase concentration of $120 \mathrm{ppmv}$, a retention coefficient of $0.99 \pm 0.08$ was determined. Obviously there is no difference between the results using ice particles or ice crystals. The results obtained with higher liquid phase concentrations are slightly higher than the ones with lower liquid phase concentrations; however, the deviation lies within the measurement error. Thus, in spite of the differences in liquid phase concentrations or experimental methods, one average value has been derived from all data.

In the experiments of $\mathrm{HCl}$ with captively floated ice particles a retention coefficient of $1.01 \pm 0.09$ was measured with a liquid phase concentration of $17 \mathrm{ppmv}$ and $0.97 \pm 0.08$ with a liquid phase concentration of $90 \mathrm{ppmv}$. For freely levitated ice crystals with an $\mathrm{HCl}$ liquid phase concentration of 90 ppmv a retention coefficient of $0.99 \pm 0.08$ was found. No significant differences between liquid phase concentrations or experimental methods were observed so that here, too, all data have been taken into account to yield an average value. Finally, average values from all experimental techniques and liquid phase concentrations are $99 \pm 8 \%$ retention for $\mathrm{HNO}_{3}$ and $100 \pm 9 \%$ for $\mathrm{HCl}$.

For both trace gases, varying the temperature did not lead to very different retention coefficients. This can be explained by the fact that in the observed ranges of temperature and liquid water content riming proceeded in the dry growth regime. That means liquid drops colliding with the ice particle freeze immediately after contact so that during this fast freezing process the chance of dissolved species to be released back to the gas phase is reduced. As long as this is the case, the retention coefficients do not show significant variations for different temperatures. Increasing ambient temperature and/or liquid water content would lead to riming in the wet growth regime, i.e. freezing would proceed much more slowly so that the dissolved species are more likely to leave and reenter the gas phase before being trapped in the ice.

\subsection{Hydrogen peroxide}

Experiments with $\mathrm{H}_{2} \mathrm{O}_{2}$ were performed with captively floating ice particles and with quasi-floating snow flakes. Fig. 5 shows the retention coefficients determined with captively floated ice particles rimed with $\mathrm{H}_{2} \mathrm{O}_{2}$ solution droplets of two different concentrations ( $1 \mathrm{ppmv}$ given as black circles, and $10 \mathrm{ppmv}$ given as open circles) plotted as function of the ambient air temperature. The retention coefficients measured with quasi-floating snow flakes rimed with solution droplets containing 1 ppmv $\mathrm{H}_{2} \mathrm{O}_{2}$ as a function of temperature are shown in Fig. 6. For both cases, there is no noticeable temperature dependence. It can easily be seen from Figs. 5 and 6 that the scatter of the data is much higher than for the other two investigated trace gases. In Table 2 it is evident that the standard deviations affected by the scatter of the 


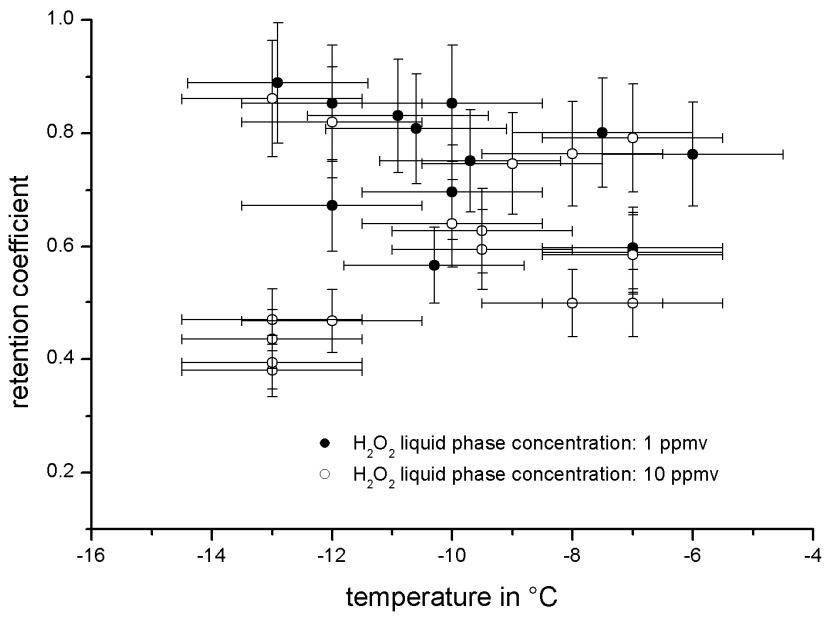

Fig. 5. Retention coefficient of $\mathrm{H}_{2} \mathrm{O}_{2}$ as a function of ambient air temperature, determined with captively floating ice particles rimed with solution droplets of two concentrations (black circles: 1 ppmv, open circles: $10 \mathrm{ppmv}$ ).

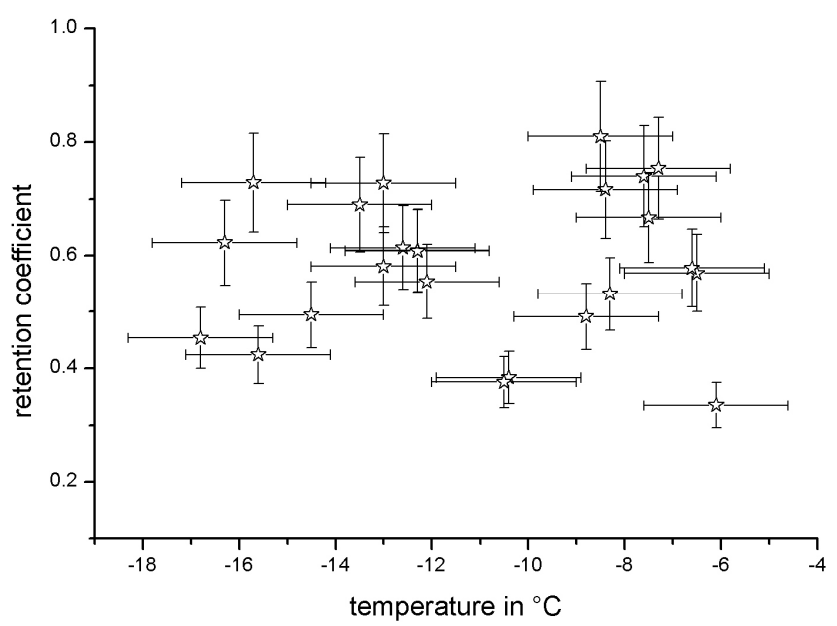

Fig. 6. Retention coefficient of $\mathrm{H}_{2} \mathrm{O}_{2}$ as a function of air temperature, determined with quasi-floating snow flakes rimed with solution droplets with a concentration of $1 \mathrm{ppmv}$.

data are in the range of the errors caused by the measurement techniques, which were calculated using the Gaussian error computation. In particular, the data measured with captively floating ice particles with higher liquid phase concentrations show more fluctuations (see Fig. 5).

Similar to the experiments with $\mathrm{HNO}_{3}$ and $\mathrm{HCl}$, varying the temperature did not lead to any significant changes of the retention coefficients because riming proceeded in the dry growth regime. However, in some cases with captively floating of graupels a slight reduction of the $\mathrm{H}_{2} \mathrm{O}_{2}$ retention coefficient was observed at the higher end of the temperature range. The rimed ice also showed a smoother surface indicating an onset of semi-dry growth. Thus, for wet growth conditions lower retention coefficients are to be expected because freezing proceeds more slowly so that a higher amount of the species might be excluded from the ice phase.

The mean values of the retention coefficients for $\mathrm{H}_{2} \mathrm{O}_{2}$ are given in Table 2 as $0.74 \pm 0.11$ for 1 ppmv liquid phase concentration and $0.60 \pm 0.10$ for 10 ppmv liquid phase concentration. For the quasi-floated snow flakes rimed with $1 \mathrm{ppmv}$ solution droplets a retention coefficient of $0.59 \pm 0.10$ was determined. It seems that the retention coefficients for lower concentrations are slightly above the values for higher concentrations but only in the case of captively floating ice particles. The retention of quasi-floating snow flakes measured with the lower liquid phase concentration does not confirm this observation. However, the deviations are within the measurement error. Thus, independent of the experimental methods and liquid phase concentrations, an average value of the retention was determined to be $64 \pm 11 \%$ for $\mathrm{H}_{2} \mathrm{O}_{2}$.

\section{Discussion and comparisons to earlier results}

\subsection{Nitric and hydrochloric acid}

From all experimental techniques and liquid phase concentrations, the mean retentions are $99 \pm 8 \%$ for $\mathrm{HNO}_{3}$ and $100 \pm 9 \%$ for $\mathrm{HCl}$. These numbers are in good agreement with the results of Iribarne and Physnov (1990) who found retention of $99 \pm 2 \%$ for $\mathrm{HNO}_{3}$ and $100 \pm 3 \%$ for $\mathrm{HCl}$. These two trace gases are highly soluble in water and afterwards, strongly dissociated so that their release during freezing is hardly possible. Thus, retention coefficients near 1 are to be expected which was also shown in the theoretical investigations of Stuart and Jacobson $(2003,2004)$. They concluded that chemicals with very high effective Henry's law constants (such as nitric and hydrochloric acid) are likely to be fully retained during riming under all freezing conditions. Thus, independent of the experimental techniques adopted in earlier investigations and those employed in the present studies, the results are very similar. The fact that the retention determined for $\mathrm{HCl}$ is always slightly higher than the one measured for $\mathrm{HNO}_{3}$ could be considered as an indicator of the effective Henry's law constant. Stuart and Jacobson (2003) calculated these for dry growth riming (which has been observed in the present experiments, see von Blohn et al., 2009) and found an effective Henry's law constant of $4.4 \times 10^{15}$ for $\mathrm{HCl}$ and a lower value of $1 \times 10^{13}$ for $\mathrm{HNO}_{3}$ (at $\mathrm{pH}=4$ and $\left.T=0{ }^{\circ} \mathrm{C}\right)$.

As the retention is dependent on the effective Henry's law constant (Stuart and Jacobson, 2003, 2004) which in turn is affected by the concentration of the solution (the higher the solute concentration, the lower the $\mathrm{pH}$ and the effective Henry's law constant) one should expect less retention with higher liquid phase concentrations. However, the measurements do not confirm such a trend. On the contrary, slightly higher retention was determined with higher liquid phase 
Table 3. Comparison of retention coefficients determined under various experimental conditions.

\begin{tabular}{llll}
\hline & \multicolumn{3}{c}{ Retention coefficients (average values) } \\
\hline Experimental conditions & $\begin{array}{l}\text { Hydrochloric acid } \\
(\mathrm{HCl})\end{array}$ & $\begin{array}{l}\text { Nitric acid } \\
\left(\mathrm{HNO}_{3}\right)\end{array}$ & $\begin{array}{l}\text { Hydrogen peroxide } \\
\left(\mathrm{H}_{2} \mathrm{O}_{2}\right)\end{array}$ \\
\hline $\begin{array}{l}\text { no ventilation } \\
\text { LWC: } 5 \mathrm{~g} \mathrm{~m}^{-3} \\
\text { (Iribarne and Physnov, }\end{array}$ & $1.00 \pm 0.03$ & $0.99 \pm 0.02$ & $1.00 \pm 0.10$ \\
1990) & & & \\
\hline $\begin{array}{l}\text { wind speed: } 9-24 \mathrm{~m} \mathrm{~s}^{-1} \\
\text { LWC: }<0.4 \mathrm{~g} \mathrm{~m}^{-3} \\
\text { (Snider et al., } 1992)\end{array}$ & - & - & $0.24 \pm 0.07$ \\
\hline $\begin{array}{l}\text { wind speed: } 9-24 \mathrm{~m} \mathrm{~s}^{-1} \\
\text { LWC: }<0.4 \mathrm{~g} \mathrm{~m}^{-3} \\
\text { (Snider and Huang, } 1998)\end{array}$ & - & & $0.05 \pm 0.02$ \\
\hline $\begin{array}{l}\text { wind speed: } 2-3 \mathrm{~m} \mathrm{~s}^{-1} \\
\begin{array}{l}\text { LWC: } 1-1.5 \mathrm{~g} \mathrm{~m}^{-3} \\
\text { (present experiments) }\end{array}\end{array}$ & $1.00 \pm 0.09$ & & \\
\hline
\end{tabular}

concentrations but this observation lies within the systematic error of the measurements. One may conclude that the influence of liquid phase concentration on the retention of $\mathrm{HNO}_{3}$ and $\mathrm{HCl}$ with their high effective Henry's law constants is not significant.

\subsection{Hydrogen peroxide}

The average value of $\mathrm{H}_{2} \mathrm{O}_{2}$ retention, independently of the experimental methods and liquid phase concentrations, was $64 \pm 11 \%$. This value of $\mathrm{H}_{2} \mathrm{O}_{2}$ retention does not agree with any of the previous findings the reasons for which can be explained by considering the experimental conditions (see Table 3).

Iribarne and Physnov (1990) who measured $100 \%$ retention utilized a chamber located in a cold room where liquid droplets with an average diameter of $39 \mu \mathrm{m}$ fell downwards to a thin ice layer which was kept at temperatures between -5 and $-12^{\circ} \mathrm{C}$. The liquid water content was $5 \mathrm{~g} \mathrm{~m}^{-3}$, the liquid phase concentrations were in the range of $30 \mathrm{ppm}$ and $3 \times 10^{4} \mathrm{ppm}$. A temperature effect on retention was not observed by Iribarne and Physnov (1990) although they mentioned wet growth conditions at higher temperatures and dry growth at temperatures lower than $-8^{\circ} \mathrm{C}$. These experiments had two major features that differ from realistic conditions. (1) a flat cooled surface was used instead of the round surface of a frozen drop or a complex surface of ice crystals, and (2) there was no ventilation during riming. Both factors could lead to higher retention coefficients. The use of a flat cooled surface leads to an unrealistic heat transfer from the droplets thereby accelerating the freezing process and affecting higher retention. Furthermore, as already supposed by
Snider et al. (1992) the unventilated conditions above the ice surface could affect a local build-up of $\mathrm{H}_{2} \mathrm{O}_{2}$ so that the ambient concentrations and subsequently the liquid phase concentrations were higher than assumed.

Snider at al. (1992) and Snider and Huang (1998) performed field laboratory measurements in winter cap and orographic clouds at a remote mountain-top site. The ambient temperature ranged from -5 to $-15^{\circ} \mathrm{C}$, the liquid water content was between 0.05 and $0.4 \mathrm{~g} \mathrm{~m}^{-3}$. They collected rime ice on different samplers. The equilibrium $\mathrm{H}_{2} \mathrm{O}_{2}$ concentrations in the supercooled liquid droplets were calculated from measurements of gaseous and aqueous $\mathrm{H}_{2} \mathrm{O}_{2}$, temperature, and liquid water content (Snider et al., 1992). Using a rotating dual-arm wire grid a retention of $24 \%$ was determined (Snider at al., 1992) while only $5 \%$ retention was measured with a system of five cylindrical rods (Snider and Huang (1998). The authors argued that in the latter case the sampling cylinders were much broader and the droplet deposition velocities were smaller both leading to lower retentions. In comparison to the Iribarne and Physnov experiments the authors mentioned that their own measurements were performed under strongly ventilated conditions, with smaller droplets and lower liquid water contents which might explain the significantly lower retention coefficients they found. They speculated that retention during riming on freely falling ice particles will be again different because ice particles collect cloud droplets at lower velocities, they are less ventilated than in their field experiments, and cloud droplets are usually larger than the ones in orographic clouds.

Indeed, the present average value of $64 \%$ is higher than the values measured by Snider et al. (1992) and Snider and Huang (1998) but lower than the result of Iribarne and 
Physnov (1990). By comparing the different conditions of the experiments two factors are important: the liquid water content and the ventilation. The Iribarne and Physnov (1990) laboratory experiments were characterized by high liquid water contents $\left(5 \mathrm{~g} \mathrm{~m}^{-3}\right)$ and no ventilation of the ice surface both leading to high retention. The field experiments by Snider $(1992,1998)$ indicated low liquid water contents in the orographic clouds (less than $0.4 \mathrm{~g} \mathrm{~m}^{-3}$ ) and strong ventilation on the mountain top (wind speeds 9 to $24 \mathrm{~m} \mathrm{~s}^{-1}$ ) both affecting low retention. During the present experiments, the liquid water content was 1 to $1.5 \mathrm{~g} \mathrm{~m}^{-3}$ which is a typical value for mixed-phase clouds where riming will proceed rather than in orographic clouds. The ventilation during the experiments was realistic because the ice particles were floating as in atmospheric clouds, i.e. the wind speed in the tunnel was between 2 and $3 \mathrm{~m} \mathrm{~s}^{-1}$. Thus, one might conclude that the present result represents a value under realistic conditions in atmospheric mixed-phase clouds.

In their theoretical model of chemical retention during hydrometeor freezing Stuart and Jacobson $(2003,2004)$ calculated a retention indicator of 1 for $\mathrm{H}_{2} \mathrm{O}_{2}$, which matched the result of Iribarne and Physnov (1990) but was not validated by Snider at al. (1992), Snider and Huang (1998) and the present experiments. However, according to Stuart and Jacobson (2003, 2004), the effective Henry's law constant which accounts for dissociation should be an important forcing factor. The retention cannot be explained by the Henry's law constant alone. For instance, the Henry's law constant is on the same order of magnitude for both $\mathrm{HNO}_{3}$ and $\mathrm{H}_{2} \mathrm{O}_{2}\left(2.1 \times 10^{5} \mathrm{M} \mathrm{atm}^{-1}\right.$ and $6.9 \times 10^{5} \mathrm{M} \mathrm{atm}^{-1}$, respectively) while the 1 st dissociation constant is orders of magnitudes different $\left(220 \mathrm{M}\right.$ and $5.1 \times 10^{-13} \mathrm{M}$, respectively) (Stuart and Jacobson, 2003). Thus, both trace gases are highly soluble but while one is strongly dissociated the other is hardly dissociated which facilitates the expulsion back into the gas phase during freezing.

Almost $100 \%$ retention under all conditions could be expected only for species with high effective Henry's law constants such as $\mathrm{HNO}_{3}$ and $\mathrm{HCl}$. On the other hand, for species with lower effective Henry's law constants other factors such as drop sizes, ventilation, and temperature become important. Thus, for $\mathrm{H}_{2} \mathrm{O}_{2}$ with an effective Henry's law constant of $1.5 \times 10^{7}$ (at $\mathrm{pH}=4$ and $T=0^{\circ} \mathrm{C}$ ), i.e. several orders of magnitudes lower than the ones of $\mathrm{HNO}_{3}$ and $\mathrm{HCl}, 100 \%$ retention are to be expected only under particular conditions. Those were obviously fulfilled in the Iribarne and Physnov (1990) experiments but are not necessarily representative for atmospheric clouds.

As mentioned in Sect. 4.1, lower retention should be expected at higher liquid phase concentrations but was not found for the strongly soluble trace gases $\mathrm{HNO}_{3}$ and $\mathrm{HCl}$. For the medium soluble trace gas $\mathrm{H}_{2} \mathrm{O}_{2}$ this trend was observed in the measurements in the case of captively floating ice particles but not confirmed in the case of quasi-floating snow flakes. As the deviations were still within the mea- surement error one might conclude that the determined average retention coefficient should be valid also for lower atmospheric liquid phase concentrations.

\section{Conclusions}

In the present studies, laboratory experiments were performed at the Mainz vertical wind tunnel to investigate riming of individual freely floating ice particles. As several previous investigations resulted in controversial values of the retention coefficient, the goal was to simulate the riming process as closely as possible to the atmosphere. While the ice particles were freely or at least captively or quasi-floating at their terminal velocities in the vertical air stream of the tunnel, the ventilation and, thus, the heat transfer proceeded in a realistic manner. The investigated ranges of temperature and liquid water content were typical for atmospheric mixedphase clouds where riming proceeds.

A critical point might be the fact that the experiments were performed under nearly laminar conditions. Earlier investigations at the wind tunnel confirmed that the collisional growth of cloud droplets is affected by turbulence (Vohl et al., 1999). Riming is the corresponding process in the ice phase and might be influenced by turbulence as well, particularly as graupel is formed mainly in convective clouds where the turbulence intensity is high (Weil et al., 1993; Pruppacher and Klett, 1997). However, no information regarding this is available in the literature so far. On the other hand, unlike collision coalescence droplet growth the riming collector particle undergoes random motions during riming growth even under laminar conditions so that additional turbulence in the ambient air might not have significant effects. Regarding the retention of trace gases, following the model of Stuart and Jacobson $(2003,2004)$ one should assume that if heat transport from the drop is affected by turbulence this should also influence the retention. However, earlier wind tunnel studies of diffusional transport to drops showed that heat and mass transport is not significantly affected by turbulence (Diehl et al., 2000). Thus, it is conjectured that the influence of turbulence on chemical retention is negligible.

For nitric and hydrochloric acid, retention near $100 \%$ was expected because of their high solubility and dissociation in water. The results obtained with the wind tunnel experiments verified earlier results and confirmed the experimental methods. For $\mathrm{H}_{2} \mathrm{O}_{2}$, lower retention is expected because its effective Henry's law constant is several orders of magnitudes lower than the ones of $\mathrm{HNO}_{3}$ and $\mathrm{HCl}$. Results from previous experiments ranged from 5 to $100 \%$ due to experimental conditions which were not well representative for freely falling riming ice particles in atmospheric mixedphase clouds.

No significant differences were found between the use of ice particles and dendritic ice crystals as rimed ice. Furthermore, the results did not show a temperature dependence 
which was explained by the fact that in the observed range of temperature and liquid water content, riming proceeded in the dry growth regime. For wet growth conditions where freezing proceeds more slowly, lower retention coefficients are expected. Therefore, average values for all investigated conditions were determined: $99 \pm 8 \%$ retention for nitric acid, $100 \pm 9 \%$ for hydrochloric acid, and $64 \pm 11 \%$ for hydrogen peroxide. The latter new average value might represent a retention coefficient applicable to theoretically simulate the effects of the ice phase on $\mathrm{H}_{2} \mathrm{O}_{2}$ gas concentration in the troposphere.

In the theoretical model of Stuart and Jacobson (2003, 2004) chemical retention during hydrometeor freezing is described based on chemical properties of the trace gases such as solubility and dissociation; however, the model is not able to explain different measured retention coefficients, in particular for hydrogen peroxide. In the present investigation it was the aim to perform the riming process as representative of riming in a natural cloud as possible and to integrate our result in the previous ones to come one step forward. A model which allows to predict retention under given physical conditions has to combine various parameters such as liquid water content, drop size, temperature, and ventilation. As base of such a model more experimental data are required where retention is measured under various controlled environmental conditions.

Acknowledgements. This study was supported by the Deutsche Forschungsgemeinschaft under the SFB 641 "The tropospheric ice phase" and the Excellence Cluster "Geocycles" of the Federal State of Rheinland-Pfalz. The authors are grateful to the anonymous reviewers for their helpful suggestions.

Edited by: B. Ervens

\section{References}

von Blohn, N., Diehl, K., Mitra, S. K., and Borrmann, S.: Wind tunnel investigations on the growth rates and regimes, and the collection kernels during riming, J. Atmos. Sci., 66, 2359-2366, 2009.

Borys, R. D., Hindman, E. E., and DeMott, P. J.: The chemical fractionation of atmospheric aerosol as a result of snow crystal formation and growth, J. Atmos. Chem., 7, 213-239, 1988.

Collett, J. L., Prévôt, A. S. H., Staehlin, J., and Waldvogel, A.: Physical factors influencing winter precipitation chemistry, Environ. Sci. Techn., 25, 782-788, 1991.

Diehl, K., Mitra, S. K., and Pruppacher, H. R.: A laboratory study of the uptake of $\mathrm{HNO}_{3}$ and $\mathrm{HCl}$ vapour by snow crystals and ice spheres at temperatures between 0 and $-40{ }^{\circ} \mathrm{C}$, Atmos. Environ., 29, 975-981, 1995.

Diehl, K., Mitra, S. K., and Pruppacher, H. R.: A laboratory study on the uptake of $\mathrm{HCl}, \mathrm{HNO}_{3}$, and $\mathrm{SO}_{2}$ gas by ice crystals and the effect of these gases on the evaporation rate of the crystals, Atmos. Res., 47-48, 235-244, 1998.
Diehl, K., Vohl, O., Mitra, S. K., and Pruppacher, H. R.: A laboratory and theoretical study on the uptake of sulfur dioxide gas by small water drops containing hydrogen peroxide under laminar and turbulent conditions. Atmos. Environ., 34, 2865-2871, 2000.

Diehl, K., Mitra, S. K., Szakáll, M., von Blohn, N., Borrmann, S., and Pruppacher, H. R.: The Mainz vertical wind tunnel facility: A review of 25 years of laboratory experiments on cloud physics and chemistry, In: J.D. Pereira (Ed.), Wind tunnels: Aerodynamics, models, and experiments. Nova Science Publishers Inc., Chapter 2, 2011.

Harimaya, T. and Nakai, Y.: Riming growth process contributing to the formation of snowfall in orographic areas of Japan facing the Japan Sea, J. Meteorol. Soc. Jpn., 77, 101-115, 1999.

Hoog, I., Mitra, S. K., Diehl, K., and Borrmann, S.: Laboratory studies about the interaction of ammonia with ice crystals at temperatures between 0 and $-20^{\circ} \mathrm{C}$, J. Atm. Chem., 57, 73-84, 2007.

Iribarne, J.V., Barrie, L.A., and Iribarne, A.: Effect of freezing on sulfur dioxide dissolved in supercooled droplets, Atmos. Environ., 17, 1047-1050, 1983.

Iribarne, J. V. and Pyshnov, T.: The effect of freezing on the composition of supercooled droplets. - I. Retention of $\mathrm{HCl}, \mathrm{HNO}_{3}$, $\mathrm{NH}_{3}$, and $\mathrm{H}_{2} \mathrm{O}_{2}$, Atmos. Environ., 24A, 383-387, 1990.

Iribarne, J. V., Pyshnov, T., and Naik, B.: The effect of freezing on the composition of supercooled droplets - II. Retention of S(IV), Atmos. Environ., 24A, 389-398, 1990.

Lamb, D. and Blumenstein, R.: Measurement of the entrapment of sulfur dioxide by rime ice, Atmos. Environ., 21, 1765-1772, 1987.

Mari, C., Jacob, D. J., and Bechthold, P.: Transport and scavenging of soluble gases in a deep convective cloud, J. Geophys. Res., 105, 22255-22267, 2000.

Mitra, S. K., Barth, S., and Pruppacher, H. R.: A laboratory study on the scavenging of $\mathrm{SO}_{2}$ by snow crystals, Atmos. Environ., 24A, 2307-2312, 1990.

Neal, M., Neal, C., Wickham, H., and Harman, S.: Determination of bromide, chloride, fluoride, nitrate and sulphate by ion chromatography: comparisons of methodologies for rainfall, cloud water and river waters at the Plynlimon catchments of midWales, Hydrol. Earth Syst. Sci., 11, 294-300, doi:10.5194/hess7-294-2007, 2007.

Prather, M. J. and Jacob, D. J.: A persistent imbalance in $\mathrm{HO}_{\mathrm{x}}$ and $\mathrm{NO}_{\mathrm{x}}$ photochemistry of the upper troposphere driven by deep tropical convection, Geophys. Res. Lett., 24, 3189-3192, 1997.

Pruppacher, H. R.: Auswaschen von atmosphärischen Spurenstoffen durch Wolken und Niederschlag mittels eines vertikalen Windkanals, BMFT-Report 9/88, GSF München, Germany, 1988.

Pruppacher, H. R. and Klett, J. D.: Microphysics of Clouds and Precipitation, 2nd ed., Kluwer Academic Publishers, Dordrecht, The Netherlands, 1997.

Römer, F. G., Viljeer, J. W., van den Beld, L., Slangewal, H. J., Veldkamp, A. A., and Reunders, H. F. R.: The chemical composition of cloud and rainwater. Results of preliminary measurements from an aircraft, Atmos. Environ., 19, 1847-1858, 1985.

Salzmann, M., Lawrence, M. G., Phillips, V. T. J., and Donner, L. J.: Model sensitivity studies regarding the role of the retention coefficient for the scavenging and redistribution of highly solu- 
ble trace gases by deep convective cloud systems, Atmos. Chem. Phys., 7, 2027-2045, doi:10.5194/acp-7-2027-2007, 2007.

Sauer, F., Schuster, G., Schäfer, C., and Moortgat, G. K.: Determination of $\mathrm{H}_{2} \mathrm{O}_{2}$ and organic peroxides in cloud and rainwater on the Kleiner Feldberg during FELDEX, Geophys. Res. Lett., 23, 2605-2608, 1996.

Snider, J. R., Montague, D. C., and Vali, G.: Hydrogen peroxide retention in rime ice, J. Geophys. Res., 97, 7569-7578, 1992.

Snider, J. R. and Huang, J.: Factors influencing the retention of hydrogen peroxide and molecular oxygen in rime ice, J. Geophys. Res., 103, 1405-1415, 1998.

Stuart, A. L. and Jacobson, M. Z.: A timescale investigation of volatile chemical retention during hydrometeor freezing: Nonrime freezing and dry growth riming without spreading, J. Geophys. Res., 108, 4178, doi:10.1029/2001JD001408, 2003.

Stuart, A. L. and Jacobson, M. Z.: Chemical retention during dry growth riming, J. Geophys. Res., 109, D07305, doi:10.1029/2003JD004197, 2004.

Szakáll, M., Diehl, K., Mitra, S. K., Borrmann, S.: Shapes and oscillations of falling raindrops - a review. Atm. Res., 97, 416425, 2010.

Valverde-Canossa, J., Wieprecht, W., Acker, K., and Moortgat, G. $\mathrm{K}$ : $\mathrm{H}_{2} \mathrm{O}_{2}$ and organic peroxide measurements in an orographic cloud: The FEBUKO experiment, Atmos. Environ., 39, 42794290, 2005.
Vohl, O.: Die dynamischen Charakteristika des Mainzer vertikalen Windkanals, Diploma thesis (Master thesis, in German), Institute of Atmospheric Physics, Johannes Gutenberg University, Mainz, Germany, 1989.

Vohl, O., Mitra, S. K., Wurzler, S. C., and Pruppacher, H. R.: A wind tunnel study of the effects of turbulence on the growth of cloud drops by collision and coalescence, J. Atmos. Sci., 56, 4088-4099, 1999.

Waltrop, A., Mitra, S. K., Flossmann, A. I., and Pruppacher, H. R.: On the scavenging of $\mathrm{SO}_{2}$ by cloud and rain drops: 4. A wind tunnel and theoretical study of the adsorption of $\mathrm{SO}_{2}$ in the $\mathrm{ppb}(\mathrm{v})$ range by water drops containing $\mathrm{H}_{2} \mathrm{O}_{2}$, J. Atm. Chem., 12, 1-17, 1991.

Warneck, P.: Chemistry of the natural atmosphere, 2nd ed., Academic Press, San Diego, CA, USA, 2000.

Weil, J. C., Lawson, R. P., and Rodi, A. R.: Relative dispersion of ice crystals in seeded cumuli. J. Appl. Meteorol., 32, 1055-1068, 1993. 